\title{
Analisis Pengaruh Kinerja Keuangan Terhadap Kemampuan Membayar Zakat
}

\author{
Ima Khoirunnisa Harianja1, Darwis Harahap², Aliman Syahuri Zein3 \\ 1,2,3Institut Agama Islam Negeri Padangsidimpuan \\ JL. H.T. Rizal Nurdin Km 4,5 Sihitang Kota Padangsidimpuan _ Sumatera Utara
}

\begin{abstract}
Abstrak
Zakat merupakan salah satu kegiatan sosial yang diemban PT. Bank Syariah Mandiri dan yang wajib dibayar apabila sudah mencapai nisab. Perhitungan dana zakat yang dikeluarkan 2,5\% dari laba sebelum pajak. Untuk mengetahui kemampuan bank dalam mengahasilkan laba secara relatif menggunakan Rasio Return On Assets (ROA) dan Return On Equity (ROE). Berdasarkan data yang diperoleh dari PT. Bank Syariah Mandiri persentase ROA, ROE dan Zakat mengalami fluktuasi pada tahun 2008-2016, namun kenaikan persentase yang terjadi pada ROA dan ROE tidak selalu diikuti dengan kenaikan zakat. Penelitian ini dilakukan untuk mengetahui apakah ROA dan ROE berpengaruh terhadap kemampuan membayar zakat PT. Bank Syariah Mandiri baik secara parsial maupun secara simultan. Data Penelitian ini merupakan penelitian kuantitatif. Dan Teknik Analisis data menggunakan metode regresi linier berganda dengan menggunakan program komputer SPSS versi 22.00. Hasil penelitian secara parsial (uji t) menyatakan bahwa ROA tidak berpenggaruh terhadap zakat. Sedangkan, ROE berpengaruh terhadap zakat. ROA dan ROE pengaruh terhadap zakat.
\end{abstract}

Kata Kunci : ROA, ROE, Zakat

\begin{abstract}
Zakat is one of the social activities carried out by PT. Bank Syariah Mandiri and that must be paid when it reaches the nisab. The calculation of zakat funds issued is $2.5 \%$ of profit before tax. To determine the ability of banks to generate relative profits using the Ratio of Return on Assets (ROA) and Return on Equity (ROE). Based on data obtained from PT. Bank Syariah Mandiri percentage of ROA, ROE and Zakat fluctuated in 2008-2016, however, the increase in percentage that occurred in ROA and ROE was not always followed by an increase in zakat. This research was conducted to determine whether ROA and ROE affect the ability to pay zakat in PT. Bank Syariah Mandiri, either partially or simultaneously. This research data is a quantitative research. And the data analysis technique used multiple linear regression method using the SPSS version 22.0O computer program. The results of the research partially ( $t$ test) state that ROA has no effect on zakat. Meanwhile, ROE affects zakat. ROA and ROE influence on zakat.
\end{abstract}

Keywords: ROA, ROE, Zakat 


\section{PENDAHULUAN}

Kehadiran bank syariah dengan filosofi bebas bunga memiliki signifikan tersendiri bagi upaya pembangunan ekonomi nasional. Sistem perbankan konvensional yang didasari suku bunga tidak begitu membantu ekonomi masyarakat menengah ke bawah, hal ini disebabkan tingkat suku bunga yang tidak mendukung berkembangnya ekonomi kerakyatan dan dianggap riba yang bertentangan dengan nilai kemanusiaan dan nilai agama (Muhammad : 2005).

Bank syariah merupakan lembaga keuangan yang kegiatan usahanya disesuaikan dengan prinsip syariah Islam (Muhammad : 2014). Usaha bank syariah yang berdasarkan prinsip syariah, yaitu prinsip pembagian keuntungan atau bagi hasil. Bank syariah merupakan bank yang secara operasional berbeda dengan bank konvensional. Salah satu ciri khas bank syariah yaitu tidak menerima atau membebani bunga kepada nasabah, akan tetapi menerima atau membebankan bagi hasil serta imbalan lain sesuai dengan akad-akad yang diperjanjikan.

Operasional bank syariah lebih mengutamakan pada sektor riil dibandingkan sektor financial sesuai dengan prinsip syariah. Lembaga keuangan syariah secara formal membentuk badan khusus yang dinamakan Dewan Pengawas Syariah (DPS) yang bertugas memberikan nasihat dan saran kepada direksi serta mengawasi kegiatan bank syariah agar sesuai dengan prinsip syariah. Dewan Pengawas Syariah (DPS) diangkat oleh rapat umum pemegang saham atas rekomendasi Majelis Umum Indonesia (MUI) (Ismail : 2011).

Pada tahun 1999, berdirilah PT. Bank Syariah Mandiri yang merupakan konversi dari Bank Susila Bakti. Bank Susila Bakti merupakan bank konvensional yang dibeli oleh Bank Dagang Negara, kemudian dikonversi menjadi Bank Syariah Mandiri, bank syariah kedua di Indonesia. Pendirian BSM menjadi pertaruhan berhasil atau gagalnya bank syariah di Indonesia. Hal ini disebabkan karena BSM merupakan bank syariah yang didirikan oleh BUMN. Ternyata BSM dengan cepat mengalami perkembangan. Hal ini ditandai dengan kemampuan lembaga tersebut membuat produk-produk yang marketable dan acceptable di tengah-tengah masyarakat sehingga rasio kecukupan modal (CAR) BSM mengalami kenaikan dari angka 32 persen menjadi sekitar 6o persen (Muhammad : 2014).

Sebagai entitas bisnis, BSM tidak hanya melakukan kegiatan bisnis atau mencari untung semata-mata. BSM juga turut aktif melakukan berbagai kegiatan sosial. Selain menjalankan fungsi di bidang perbankan, bank syariah juga mempunyai fungsi sosial salah satunya melalui zakat. BSM akan menghimpun dana zakat dari masyarakat, pegawai bank, serta bank syariah sendiri sebagai lembaga milik para insvestor, dan dana yang dihimpun BSM akan disalurkan kepada yang berhak dalam bantuan atau hibah untuk memenuhi kehidupan yang lebih sejahtera.

JISFIM: Journal of Islamic Social Finance Management, Volume 1, No 2 Tahun 2020 http://jurnal.iain-padangsidimpuan.ac.id/index.php/JISFIM 
Zakat menurut Undang-Undang No. 23 Tahun 2011 pasal 1 Ayat 2 adalah harta yang wajib dikeluarkan oleh seorang muslim atau badan usaha untuk diberikan kepada yang berhak menerimanya sesuai dengan syariat Islam (Soemitra : 2009). Zakat adalah sebagian harta yang wajib dikeluarkan oleh wajib zakat (muzakki) untuk diserahkan kepada penerima zakat (mustahiq). Pembayaran zakat dilakukan apabila nisab dan haulnya terpenuhi dari harta yang memenuhi kriteria wajib zakat (Yaya dkk : 2014).

Berdasarkan pengertian tersebut dapat diketahui bahwa bank syariah sebagai suatu badan usaha yang dimiliki dan dikelola umat muslim sudah kewajibannya untuk membayar ataupun mengeluarkan zakat apabila sudah mencapai nisab zakat yang telah ditentukan. Zakat yang dibayarkan mencerminkan kepedulian perusahaan kepada kesejahteraan manusia dan alam lingkungan karena zakat akan diberikan sebagai santunan kepada mereka. Selain itu yang paling penting bahwa zakat adalah penghubung kehidupan duniawi dengan hal-hal yang akan dipertanggungjawabkan manusia kelak di akhirat.

Bank syariah sebagai salah satu lembaga keuangan yang berlandaskan pada Alquran dan Hadis memiliki peran penting dalam pembangunan ekonomi masyarakat. Salah satu upaya yang dianjurkan dalam Alquran dan Hadis untuk mewujudkan kesejahteraan masyarakat yaitu melalui zakat. Hal ini sesuai dengan tujuan sosial yang dilakukan bank syariah termasuk Bank Syariah Mandiri. Menurut Della Silvia, Zakat Bank Syariah Mandiri dikeluarkan dari zakat pegawai, zakat pendapatan dan zakat aset. Zakat pegawai yaitu zakat yang dikeluarkan dari gaji pokok pegawai tiap bulannya. Zakat pendapatan yaitu zakat yang dikeluarkan dari pendapatan bank. Zakat aset dikeluarkan dari aset bank tersebut.

Dalam penelitian ini, peneliti hanya membahas zakat pendapatan yang dikeluarkan pihak Bank Syariah Mandiri sebagaimana yang telah ditetapkan perhitungan zakat perusahaan didasarkan pada laporan keuangan dengan mengurangkan kewajiban atas aktiva lancar atau dikurangi pembayaran utang dan kewajiban lainnya, zakat yang wajib dikeluarkan adalah 2,5\% (2,5\% dari laba sebelum pajak)(Hafidhuddin : 2002). Untuk mengetahui perhitungan dana zakat dan kinerja bank diperlukan adanya laporan keuangan secara umum yang sudah berlaku. Laporan keuangan menyajikan hal-hal penting dari perusahaan yang berupa kinerja keuangan bank. Dari kinerja keuangan tersebut dapat diketahui jumlah zakat yang dikeluarkan bank syariah.

Kinerja keuangan bank merupakan gambaran kondisi keuangan bank pada suatu periode tertentu baik menyangkut aspek penghimpunan dana maupun aspek penyaluran dana yang biasanya diukur dengan indikator kecukupan modal, likuiditas, dan profitabilitas (Jumingan : 2011). Penilaian aspek profitabilitas guna mengetahui kemampuan menciptakan 
profit sangat berhubungan dalam penentuan pembayaran zakat perusahaan. Dengan kinerja bank yang baik pada akhirnya akan berdampak baik pada pihak dalam maupun bagi pihak luar bank.

Informasi kinerja perusahaan terutama profitabilitas diperlukan untuk menilai perubahan potensi sumber daya ekonomi yang mungkin dikendalikan dimasa depan. Informasi fluktuasi kinerja bermanfaat untuk memprediksi kapasitas perusahaan dalam menghasilkan arus kas dari sumber daya yang ada, disamping itu informasi tersebut juga dapat berguna dalam perumusan pertimbangan tentang efektifitas perusahaan dalam memanfaatkan tambahan sumber daya. Laporan keuangan menyajikan hal-hal penting dari pribadi perusahaan yang berupa laba, tetapi dari laba yang diperoleh perusahaan dialokasikan sebagai zakat. Rasio merupakan alat ukur yang digunakan perusahaan untuk menganalisis laporan keuangan.

Rasio menggambarkan suatu hubungan atau pertimbangan antara suatu jumlah tertentu dengan jumlah yang lain. Dengan menggunakan alat analisa yang berupa rasio keuangan dapat menjelaskan dan memberikan gambaran kepada penganalisa tentang baik dan buruknya keadaan atau posisi keuangan dari suatu perusahaan. Rasio-rasio keuangan yang digunakan dalam penelitian ini merupakan rasio profitabilitas (ROA dan ROE), yang erat hubungannya dengan laba perusahaan. Karena zakat perusahaan berhubungan erat dengan laba perusahaan, apabila laba naik maka secara tidak langsung akan mempengaruhi zakat perusahaan yang akan dikeluarkan.

Return On Assest (ROA) adalah rasio yang digunakan untuk mengetahui kemampuan bank mengahasilkan keuntungan secara relatif dengan nilai total asetnya (Sutanto dan Umam : 2013). Sebaliknya, semakin kecil rasio ini mengindikasikan kurangnya kemampuan manajemen bank dalam hal mengelola aktiva untuk meningkatkan pendapatan dan menekan biaya (Rivai dan Arifin : 2010). Rasio ini digunakan manajemen dalam memperoleh keuntungan (laba) secara keseluruhan. Semakin besar ROA, semakin besar pula tingkat keuntungan yang dicapai dan semakin baik pula posisi dari segi penggunaan asset (Rivai dan Veithzal : 2008). Berdasarkan definisi di atas dapat dijelaskan bahwa tinggi rendahnya ROA tergantung pada pengelolaan aset manajemen yang menggambarkan efisiensi dan operasional perusahaan. Semakin tinggi rasio ini maka semakin menunjukkan efektifitas dalam menghasilkan laba dengan pemanfaatan modal sendiri, dan sebaliknya jika rasio ini rendah maka pengelolaan akan modal sendiri masih kurang. Jika suatu perusahaan mempunyai ROA yang tinggi maka perusahaan tersebut berpeluang besar dalam pembayaran angka zakat yang tinggi.

Return On Equity (ROE) merupakan rasio yang mengukur kemampuan bank dalam mengelola dana yang diinvestasikan dalam keseluruhan modal yang menghasilkan keuntungan. 
Dari pandangan para pemilik, ROE adalah ukuran yang lebih penting karena merefleksikan kepentingan kepemilikan mereka. Di Indonesia, BI menetapkan angka ROE diatas 12\% agar suatu bank dapat diakatakan dalam kondisi sehat (Manurung : 2004)

Berdasarkan penjelasan di atas dapat diketahui kinerja keuangan sangat berpengaruh terhadap kemampuan membayar zakat perusahaan. Dalam menghitung angka zakat perusahaan yaitu dengan mengetahui laba perusahaan yang diuraikan atau diukur melalui rasio profitabilitas (ROA dan ROE). Semakin tinggi nilai ROA dan ROE maka akan semakin tinggi angka zakat yang dikeluarkan perusahaan tersebut. Adapun indikator kinerja keuangan PT. Bank Syariah Mandiri dapat dilihat pada tabel sebagai berikut:

Tabel 1

Indikator Kinerja Keuanngan PT. Bank Syariah Mandiri

\begin{tabular}{|c|c|c|c|c|}
\hline Tahun & Triwulan & ROA (\%) & ROE (\%) & $\begin{array}{c}\text { Zakat (dalam } \\
\text { jutaan } \\
\text { rupiah) }\end{array}$ \\
\hline 2008 & $\mathrm{I}$ & 2,05 & 51,61 & 1.728 \\
\hline 2008 & II & 1,94 & 51,35 & 3.528 \\
\hline 2008 & III & 1,91 & 48,78 & 5.415 \\
\hline 2008 & IV & 1,83 & 46,21 & 7.102 \\
\hline 2009 & I & 2,08 & 38,77 & 2.269 \\
\hline 2009 & II & 2,00 & 38,21 & 4.464 \\
\hline 2009 & III & 2,11 & 40,17 & 7.166 \\
\hline 2009 & IV & 2,23 & 44,20 & 10.160 \\
\hline 2010 & $\mathrm{I}$ & 2,04 & 53,10 & 2.978 \\
\hline 2010 & II & 2,22 & 60,04 & 6.718 \\
\hline 2010 & III & 2,30 & 64,83 & 10.891 \\
\hline 2010 & IV & 2,21 & 63,58 & 14.218 \\
\hline 2011 & I & 2,22 & 74,43 & 4.604 \\
\hline 2011 & II & 2,12 & 68,22 & 9.085 \\
\hline 2011 & III & 2,03 & 67,03 & 13.818 \\
\hline 2011 & IV & 1,95 & 64,84 & 18.698 \\
\hline 2012 & $\mathrm{I}$ & 2,17 & 66,56 & 6.511 \\
\hline 2012 & II & 2,25 & 68,52 & 13.405 \\
\hline 2012 & III & 2,22 & 68,43 & 19.947 \\
\hline
\end{tabular}

JISFIM: Journal of Islamic Social Finance Management, Volume 1, No 2 Tahun 2020 http://jurnal.iain-padangsidimpuan.ac.id/index.php/JISFIM 


\begin{tabular}{|c|c|c|c|c|}
\hline 2012 & IV & 2,25 & 68,09 & 27.428 \\
\hline 2013 & I & 2,56 & 70,11 & 8.578 \\
\hline 2013 & II & 1,79 & 50,30 & 12.341 \\
\hline 2013 & III & 1,51 & 43,49 & 15.996 \\
\hline 2013 & IV & 1,53 & 44,58 & 22.095 \\
\hline 2014 & I & 1,77 & 53,86 & 6.736 \\
\hline 2014 & II & 0,66 & 20,17 & 5.103 \\
\hline 2014 & III & 0,80 & 24,64 & $9 \cdot 327$ \\
\hline 2014 & IV & 0,17 & 4,82 & 2.744 \\
\hline 2015 & I & 0,81 & 25,61 & 3.268 \\
\hline 2015 & II & 0,55 & 5,48 & 4.596 \\
\hline 2015 & III & 0,42 & 4,10 & 5.228 \\
\hline 2015 & IV & 0,56 & 5,92 & 8.678 \\
\hline 2016 & I & 0,56 & 5,61 & 2.502 \\
\hline 2016 & II & 0,62 & 6,14 & 5.550 \\
\hline 2016 & III & 0,60 & 5,98 & 8.141 \\
\hline 2016 & IV & 0,59 & 5,81 & 10.867 \\
\hline
\end{tabular}

Sumber: Publikasi Laporan Keuangan PT. Bank Syariah Mandiri

Berdasarkan tabel 1 di atas ROA PT. Bank Syariah Mandiri pada tahun 2011 triwulan pertama sebesar 2,22\% dan triwulan kedua sebesar 2,12\% atau mengalami penurunan sebesar 0,80\%. Pada tahun 2012 triwulan ketiga sebesar 2,22\% dan triwulan keempat sebesar 2,25\% atau meningkat sebesar $0,03 \%$. Sedangkan pada tahun 2013 triwulan pertama sebesar 2,56\% dan triwulan kedua sebesar 1,79\% atau mengalami penurunan sebesar 0,77\%. Pada tahun 2014 triwulan ketiga sebesar $0,80 \%$ dan triwulan keempat sebesar $0,17 \%$ atau mengalami penurunan sebesar 0,63\%. Mengacu pada ROA tertinggi sebesar 2,56\% pada tahun 2013 triwulan pertama. ROA terendah sebesar 0,17\% pada tahun 2014 triwulan keempat.

Sementara ROE PT. Bank Syariah Mandiri pada tahun 2011 triwulan pertama sebesar $74,43 \%$ dan pada triwulan kedua sebesar $68,22 \%$ atau mengalami penurunan $6,21 \%$. Pada tahun 2012 pada triwulan kedua sebesar $68,52 \%$ dan triwulan ketiga sebesar $68,43 \%$ atau mengalami penurunan sebesar 0,09\%. Pada tahun 2013 triwulan pertama sebesar 70,11\% dan triwulan kedua sebesar 50,30\% atau mengalami penurunan 19,81\%. Pada tahun 2014 triwulan ketiga sebesar 24,64\% dan pada triwulan keempat sebesar 4,82\% atau mengalami penurunan sebesar 19,82\%. Mengacu pada ROE tertinggi sebesar 74,43\% pada tahun 2011 triwulan pertama. ROE terendah sebesar 4,82\% pada tahun 2014 triwulan keempat. JISFIM: Journal of Islamic Social Finance Management, Volume 1, No 2 Tahun 2020 http://jurnal.iain-padangsidimpuan.ac.id/index.php/JISFIM 
Fluktuasi yang terjadi pada ROA dan ROE tidak sama dengan zakat yang dikeluarkan BSM yang relatif mengalami peningkatan setiap triwulan. Dimana zakat BSM pada tahun 2011 triwulan kedua sebesar Rp 9.085 juta dan triwulan keempat sebesar Rp 18.698 juta atau meningkat sebsesar Rp 9.613 juta. Tahun 2015 triwulan kedua sebesar Rp 4.596 juta dan pada triwulan keempat sebesar Rp 8.768 juta atau meningkat sebesar Rp 4.172 juta. Pembayaran zakat tertinggi BSM pada tahun 2012 triwulan keempat sebesar Rp 27.428 juta dan pembayaran zakat terendah pada tahun 2008 triwulan pertama sebesar Rp 1728 juta.

Peningkatan yang terjadi pada zakat BSM tidak sama dengan ROA dan ROE yang dimiliki PT. Bank Syariah Mandiri yang justru mengalami fluktuasi tahun 2008 sampai 2016. Sedangkan menurut Triyuwono, melalui zakat dapat diketahui kinerja perusahaan yaitu semakin tinggi zakat yang dikeluarkan oleh perusahaan berarti semakin besar laba yang didapat perusahaan (Muhammad : 2002). Berdasarkan teori tersebut seharusnya pada waktu ROA dan ROE meningkat maka zakat bank syariah akan meningkat karena pada posisi tersebut bank menunjukkan efektifitas dalam mecari laba. Teori ini tidak sesuai dengan data yang diperoleh oleh peneliti. Berdasarkan hasil penelitian Sri Zaitun menyatakan dalam penelitiannya menunjukkan bahwa secara simultan faktor-faktor Return On Assets (ROA), Return On Equity (ROE), Loan Deposit Ratio (LDR), current rasio (CR), Debt to Assets Ration (DtAR) dan Equty Multiflier (EM) berpengaruh secara statistik signifikan terhadap zakat, akan tetapi secara parsial hanya CR dan DtAR saja yang berpengaruh secarah statistik signifikan terhadap zakat (Zaitun : 2001).

\section{METODE PENELITIAN}

Jenis penelitian ini adalah penelitian kuantitatif. Data kuantitatif yaitu data yang berbentuk angka atau data kualitatif yang diangkakan (Sugiyono : 2005). Metode ini menggunakan pendekatan deskriptif, karena penelitian ini dilakukan untuk mengumpulkan data yang akan diuji dan atau menjawab pertanyaan mengenai status terakhir suatu objek yang diteliti. Penelitian ini dilakukan berdasarkan runtun waktu (time series) yaitu data satu individu yang diobservasi dalam rentangan waktu atau dapat dikatakan bahwa data time series merupakan sejarah karateristik tertentu suatu individu (Djalal : 2006). Adapun populasi dalam penelitian ini adalah laporan keuangan Triwulanan Bank Syariah Mandiri periode tahun 2005 sampai pada tahun 2017 dan sampel dari penelitian ini yaitu laporan keuangan triwulan PT. Bank Syariah Mandiri ROA, ROE dan zakat tahun 2008-2016 dengan jumlah sampel sebanyak 36 dengan teknik sampling yang digunakan adalah purposive sampling yaitu sampel diambil 
dengan maksud atau tujuan tertentu. Subjek yang diambil sebagai sampel dianggap dapat menggambarkan (menjawab) apa yang menjadi tujuan dan permasalahan penelitian.

Teknik analisis data yang digunakan pertama-tama adalah uji normalitas. Uji normalis adalah untuk menguji apakah nilai residual yang dihasilkan dari regresi terdistribusi normal atau tidak. Model regresi yang baik adalah yang memiliki nilai residual yang terdistribusi secara normal (Priyatno : 2014). Uji normalis yang digunakan adalah metode uji One Sample Kolmogrow Smirnov. Sebelum melakukan uji hipotesis, perlu dilakukan pengujian persyarat analisis regresi dalam statistik parametrik. Karena dalam penggunaan statistik parametrik, bekerja dengan asumsi bahwa data setiap variabel penelitian yang akan dianalisis harus berbentuk distribusi normal (Sugiyono : 2005). Pengujian asumsi klasik bertujuan untuk mengetahui apakah hasil analisis regresi yang dilakukan terbebas dari adanya gejala multikolinearitas, heteroskedastisitas dan autokorelasi. Kemudian dilakukan uji hipotesis untuk melihat pengaruh dan besaran pengaruh variable independent terhadap variable dependennya melalui uji $\mathrm{t}$, uji f dan koefisien determinasi. Sehingga menghasilkan analisis regresi linier berganda, analisis regresi linier berganda digunakan untuk mengetahui pengaruh atau hubungan secara linier antara dua atau lebih variabel independen dengan satu variabel dependen (Sugiyono : 2005).

Persamaan regresi linier berganda dengan 2 variabel independen sebagai berikut:

Keterangan:

$$
\mathrm{Y}^{\prime}=\alpha+\beta_{1} \mathrm{X}_{1}+\beta_{2} \mathrm{X}_{2} \text { atau } \text { Zakat }=\alpha+\beta_{1} \mathrm{ROA}+\beta_{2} \mathrm{ROE}
$$

Zakat : Nilai prediksi variabel dependen (zakat)

a : Konstanta, yaitu nilai $Y^{\prime}$ jika $X_{1}$ dan $X_{2}=0$

$\beta_{1} \beta_{2} \quad$ : koefisien regresi linier berganda

ROA : Return On Assets

ROE : Return On Equity

\section{HASIL DAN PEMBAHASAN}

Penelitian yang dilakukan oleh peneliti merupakan penelitian dengan mengolah data sekunder yang diperoleh dari publikasi laporan PT. Bank Syariah Mandiri dari situs resmi Bank Syariah Mandiri yaitu www.syariahmandiri.co.id, dari laporan tersebut peneliti menggunakan periode selama 9 tahun. Adapun sampel tersebut yaitu ROA, ROE, dan zakat dari tahun 2008 sampai 2016. Untuk memperoleh nilai rata-rata, minimum, maksimum, dan standar deviasi dapat dilihat pada tabel di bawah ini: 
Tabel 2

Hasil Uji Statistik Deskriptif

\begin{tabular}{|l|r|r|r|r|r|}
\hline & $\mathrm{N}$ & $\begin{array}{r}\text { Minimu } \\
\mathrm{m}\end{array}$ & $\begin{array}{r}\text { Maximu } \\
\mathrm{m}\end{array}$ & \multicolumn{1}{c|}{ Mean } & \multicolumn{1}{c|}{$\begin{array}{c}\text { Std. } \\
\text { Deviation }\end{array}$} \\
\hline ROA & 36 &, 17 & 2,56 & 1,6008 &, 72313 \\
ROE & 36 & 4,10 & 74,43 & 42,3219 & 23,90941 \\
ZAKAT & 36 & 16,67 & 19,43 & 18,0933 &, 68049 \\
Valid N & 36 & & & & \\
(listwise) & & & & & \\
\hline
\end{tabular}

Berdasarkan Tabel 2 di atas diketahui bahwa rata-rata ROA adalah 1,6008, rata-rata ROE 42,3219, dan rata-rata zakat 18,0933. Untuk nilai minimum ROA sebesar 0,17, nilai minimum ROE sebesar 4,10, dan nilai minimum zakat sebesar 16,67. Untuk nilai maksimum ROA sebesar 2,56, maksimum ROE sebesar 74,43, dan maksimum zakat sebesar 19,43. Standar deviasi ROA sebesar 0,72313, standar deviasi ROE sebesar 23,9094, dan standar deviasi zakat sebesar 0,68049 .

\section{Uji Normalitas Data}

Uji normalis yang digunakan adalah metode uji One Sample Kolmogrow Smirnov digunakan untuk mengetahui distiribusi data, apakah mengikuti distribusi normal, poisson, uniform, atau exponential.

\section{Tabel 3}

\section{Uji Normalitas}

One-Sample Kolmogorov-Smirnov Test

\begin{tabular}{|ll|r|r|r|}
\hline & & \multicolumn{1}{c|}{ ROA } & \multicolumn{1}{c|}{ ROE } & \multicolumn{1}{c|}{ TN ZAKA } \\
\hline N & & 36 & 36 & 36 \\
Normal Parameters & Mean & 1,6008 & 42,3219 & 18,0933 \\
& Std. &, 72313 & 23,90941 &, 68049 \\
& Deviation & & & \\
Most Extreme & Absolute &, 231 &, 157 &, 052 \\
Differences & Positive &, 168 &, 157 &, 048 \\
& Negative &,- 231 &,- 131 &,- 052 \\
Test Statistic & &, 231 &, 157 &, 052 \\
Asymp. Sig. (2-tailed) & &, OOO $^{\mathrm{c}}$ &, $025^{\mathrm{c}}$ &, $200^{\mathrm{c}, \mathrm{d}}$ \\
\hline
\end{tabular}

JISFIM: Journal of Islamic Social Finance Management, Volume 1, No 2 Tahun 2020 http://jurnal.iain-padangsidimpuan.ac.id/index.php/JISFIM 
a. Test distribution is Normal.

b. Calculated from data.

c. Lilliefors Significance Correction.

$\mathrm{d}$. This is a lower bound of the true significance.

Berdasarkan tabel 3 di atas terlihat bahwa nilai absolute dari ROA sebesar 0,231, ROE sebesar 0,157, dan zakat sebesar 0,52 artinya > 0,05. Jadi, dapat disimpulkan bahwa data variabel ROA, ROE, dan zakat terdistribusi normal dengan menggunakan uji KolmogorovSmirnov.

\section{Uji Asumsi Klasik}

\section{Uji Multikolinearitas}

Multikolinearitas artinya antar variabel independen yang terdapat dalam model regresi memilki hubungan linier yang sempurna atau mendekati sempurna. Model regresi yang baik seharusnya tidak terjadi korelasi di antara variabel bebasnya. Untuk mengetahui ada atau tidaknya gejaa multikolinieritas dengan melihat nilai Variance Inflation Factor (VIF) dan Tolerance, apabila nilai VIF kurang dari 10 dan Tolerance lebih dari 0,1 maka dinyatakan tidak terjadi multikolinieritas. Hasil perhitungan uji multikolinieritas dilihat pada tabel di bawah ini:

\section{Tabel 4}

Uji Multikolinieritas

\begin{tabular}{|c|c|c|c|c|c|}
\hline \multirow[b]{2}{*}{ Model } & \multicolumn{2}{|c|}{$\begin{array}{c}\text { Unstandardized } \\
\text { Coefficients }\end{array}$} & $\begin{array}{l}\text { Standardize } \\
\text { d } \\
\text { Coefficients }\end{array}$ & \multicolumn{2}{|c|}{$\begin{array}{c}\text { Collinearity } \\
\text { Statistics }\end{array}$} \\
\hline & B & Std. Error & Beta & $\begin{array}{c}\text { Toleran } \\
\text { ce }\end{array}$ & VIF \\
\hline $\begin{array}{ll}1 & \text { (Consta } \\
& \text { nt) }\end{array}$ & 17,884 & ,273 & & & \\
\hline ROA &,- 625 & ,421 &,- 664 & 121 & 8,231 \\
\hline ROE & ,029 & ,013 & 1,004 & 121 & 8,231 \\
\hline
\end{tabular}

Berdasarkan tabel 4 di atas dapat terlihat bahwa nilai VIF dari variabel ROA dan ROE sebesar 8,231 artinya < 10, dan Tolerance dari variabel ROA dan ROE sebesar 0,121 artinya > o,1. Jadi, dapat disimpulkan bahwa variabel ROA dan ROE tidak terjadi gejala multikolinieritas.

\section{Uji Heteroskedastisitas}

JISFIM: Journal of Islamic Social Finance Management, Volume 1, No 2 Tahun 2020 http://jurnal.iain-padangsidimpuan.ac.id/index.php/JISFIM 
Uji heteroskedastisitas adalah keadaan dimana dalam model regresi terjadi ketidaksamaan varian dari residual pada satu pengamatan ke pengamatan yang lain. Model regresi yang baik adalah tidak terjadi heteroskedastisitas. Uji heteroskedastisitas dengan cara menggunakan uji glejser dengan cara meregresikan antara variabel independen dengan nilai residualnya independen dengan absolut residual lebih dari 0,05 maka tidak terjadi masalah heteroskedastisitas. Hasil perhitungan uji heteroskedastisitas dilihat pada tabel di bawah ini:

Tabel 5

Uji Heteroskedastisitas

\begin{tabular}{|c|c|c|c|c|c|}
\hline \multirow[b]{2}{*}{ Model } & \multicolumn{2}{|c|}{$\begin{array}{l}\text { Unstandardized } \\
\text { Coefficients }\end{array}$} & $\begin{array}{l}\text { Standardize } \\
\text { d } \\
\text { Coefficients }\end{array}$ & \multirow[b]{2}{*}{$\mathrm{t}$} & \multirow[b]{2}{*}{ Sig. } \\
\hline & B & Std. Error & Beta & & \\
\hline $\begin{array}{l}1 \text { (Constant } \\
\text { ) }\end{array}$ & ,489 & 153 & & 3,202 & ,003 \\
\hline ROA &,- 052 & 235 &,- 110 &,- 221 & ,827 \\
\hline ROE & ,002 & ,007 & 151 &, 302 & ,764 \\
\hline
\end{tabular}

a. Dependent Variable: ABS_RES

Berdasarkan tabel 5 di atas dapat terlihat bahwa nilai signifikansi ROA sebesar 0,827 dan ROE sebesar 0,764, artinya kedua variabel independen > 0,05. Dengan demikian dapat disimpulkan bahwa tidak terjadi masalah heteroskedastisitas pada model regresi.

\section{Uji Autokorelasi}

Uji autokorelasi digunakan untuk mengetahui ada atau tidaknya penyimpangan asumsi klasik autokorelasi, yaitu korelasi yang terjadi antara residual pada satu pengamatan dengan pengamatan lain pada model regresi. Prasyarat yang harus terpenuhi adalah tidak adanya autokorelasi dalam model regresi. Ukuran dalam menentukan ada tidaknya masalah autokorelasi dengan uji Durbin-Watson (uji D-W) dengan ketentuan nilai DW lebih besar dari 2 dan lebih kecil dari +2 . Hasil perhitungan uji autokorelasi dilihat pada tabel di bawah ini:

\section{Tabel 6}

\section{Uji Auotokorelasi}

\begin{tabular}{|l|c|r|r|r|r|}
\hline Model & $\mathrm{R}$ & $\mathrm{R}$ Square & $\begin{array}{c}\text { Adjusted R } \\
\text { Square }\end{array}$ & $\begin{array}{c}\text { Std. Error of } \\
\text { the Estimate }\end{array}$ & $\begin{array}{c}\text { Durbin- } \\
\text { Watson }\end{array}$ \\
\hline 1 &, $446^{\mathrm{a}}$ &, 199 &, 151 &, 62712 & 1,378 \\
\hline
\end{tabular}

a. Predictors: (Constant), ROE, ROA

JISFIM: Journal of Islamic Social Finance Management, Volume 1, No 2 Tahun 2020 http://jurnal.iain-padangsidimpuan.ac.id/index.php/JISFIM 
b. Dependent Variable: ZAKAT

Berdasarkan Tabel 6 di atas dapat dilihat nilai dari Durbin-Watson sebesar 1,378 sehingga dapat dinyatakan tidak terjadi autokorelasi. Hal ini dikarenakan nilai Durbin-Watson lebih besar dari -2 dan lebih kecil +2. Jadi, dapat disimpulkan tidak terdapat hubungan antar periode yang terjadi antara variabel bebas (ROA dan ROE) terhadap Zakat.

\section{Analisis regresi Linier Berganda}

Analisis regresi linier berganda digunakan untuk mengetahui pengaruh atau hubungan secara linier antara dua atau lebih variabel independen dengan satu variabel dependen. Penelitian ini akan menentukan bagaimana hubungan ROA dan ROE terhadap zakat. Dalam hal ini peneliti mencari hubungan antara variabel-variabel tersebut.

Tabel 7

Analisis Regresi Linier Berganda

\begin{tabular}{|c|c|c|c|c|c|}
\hline \multirow[b]{2}{*}{ Model } & \multicolumn{2}{|c|}{$\begin{array}{l}\text { Unstandardized } \\
\text { Coefficients }\end{array}$} & \multirow{2}{*}{$\begin{array}{c}\text { Standardized } \\
\text { Coefficients } \\
\text { Beta }\end{array}$} & \multirow[b]{2}{*}{$\mathrm{T}$} & \multirow[b]{2}{*}{ Sig. } \\
\hline & B & $\begin{array}{l}\text { Std. } \\
\text { Error }\end{array}$ & & & \\
\hline $\begin{array}{l}1 \text { (Constant } \\
\text { ) }\end{array}$ & 17,884 & 273 & & 65,485 & , OOO \\
\hline ROA &,- 625 & ,421 &,- 664 & $-1,486$ & 147 \\
\hline ROE & ,029 & ,013 & 1,004 & 2,247 & ,o31 \\
\hline
\end{tabular}

a. Dependent Variable: ZAKAT

Berdasarkan hasil pengukuran regresi yang ditunjukkan pada tabel 4.9 di atas, maka persamaan regresi yang terbentuk adalah:

$$
\text { Zakat }=\alpha+\beta_{1} \mathrm{ROA}+\beta_{2} \mathrm{ROE}
$$

Sehingga Y' = 17,884-0,625 ROA + 0,029 ROE.

Berdasarkan persamaan regresi tersebut dapat diartikan sebagai berikut, jika ROA dan ROE diasumsikan o maka zakat sebesar 17,884. Setiap peningkatan ROE sebesar 1 satuan persen, maka akan meningkatkan zakat sebesar 0,029 satuan persen dengan asumsi variabel independen lain nilainya tetap. Standar Error yaitu angka yang menunjukkan kemampuan model untuk memprediksikan variabel dependen. semakin kecil angka ini maka model regresi semakin tepat digunakan untuk memprediksi zakat. 


\section{Koefisien Determinasi $\left(\mathbf{R}^{2}\right)$}

Koefisien detreminasi $\left(\mathrm{R}^{2}\right)$ pada intinya mengukur seberapa jauh kemampuan model dalam menjelaskan variasi variabel dependen. Bila nilai $\mathrm{R}^{2}$ kecil berarti kemampuan variabelvariabel independen dalam menjelaskan variasi variabel dependen sangat terbatas. Berikut hasil uji determinasi $\mathrm{R}^{2}$ dapat dilihat sebagai berikut :

Tabel 8

Uji Koefisien Determinasi

\begin{tabular}{|l|r|r|r|r|}
\hline Model & R & R Square & \multicolumn{1}{c|}{$\begin{array}{c}\text { Adjusted R } \\
\text { Square }\end{array}$} & $\begin{array}{c}\text { Std. Error of } \\
\text { the Estimate }\end{array}$ \\
\hline 1 &, $446^{\mathrm{a}}$ &, 199 &, 151 &, 62712 \\
\hline
\end{tabular}

a. Predictors: (Constant), ROE, ROA

b. Dependent Variable: ZAKAT

Berdasarkan Tabel 8 di atas diperoleh $\mathrm{R}^{2}$ sebesar 0,199 atau 19,9\%. Hal ini menunjukkan bahwa variasi variabel dependen yaitu ROA dan ROE dapat dijelaskan oleh variasi variabel independen yaitu zakat sebesar 19,9\%, sedangkan sisanya 81,1\% dipengaruhi atau dijelaskan oleh variabel lain diluar model penelitian ini.

\section{Uji Signifikan Parsial (Uji-t)}

Untuk mengetahui apakah koefisien regresi signifikan atau tidak, maka digunakan uji t untuk menguji signifikansi konstanta dan variabel.

Tabel 9

Hasil Uji Parsial (Uji-t)

\begin{tabular}{|c|c|c|c|c|c|}
\hline \multirow[b]{2}{*}{ Model } & \multicolumn{2}{|c|}{$\begin{array}{l}\text { Unstandardized } \\
\text { Coefficients }\end{array}$} & $\begin{array}{l}\text { Standardized } \\
\text { Coefficients }\end{array}$ & \multirow[b]{2}{*}{$\mathrm{t}$} & \multirow[b]{2}{*}{ Sig. } \\
\hline & B & $\begin{array}{l}\text { Std. } \\
\text { Error }\end{array}$ & Beta & & \\
\hline $\begin{array}{c}1 \text { Constant } \\
\text { ) }\end{array}$ & 8,674 & ,273 & & 31,760 & , OOO \\
\hline ROA &,- 625 & ,421 &,- 664 & $-1,486$ & 147 \\
\hline ROE & ,029 & ,013 & 1,004 & 2,247 & , o31 \\
\hline
\end{tabular}

a. Dependent Variable: ZAKAT

Berdasarkan Tabel 9 di atas dapat dilihat bahwa variabel ROA memiliki $t_{\text {hitung }}$ sebesar 1,486, dengan nilai signifikan o,147>0,05 maka $\mathrm{H}_{\mathrm{a}}$ ditolak. Berarti secara parsial tidak terdapat 
pengaruh signifikan ROA terhadap zakat. Hal ini disebabkan ROA juga dipengaruhi total aset, sementara total aset pada BSM tidak selalu tetap. Sehingga total aset yang dimiliki mempunyai pengaruh yang besar dalam memoderasi pengaruh ROA terhadap zakat.

Sedangkan untuk variabel ROE nilai thitung sebesar 2,247 dan tabel sebesar 2,03452 sehingga $t_{\text {hitung }}>t_{\text {tabel }}(2,247>2,03452)$ maka $H_{o}$ ditolak dan $H_{a}$ diterima. Sehingga dapat ditarik kesimpulan bahwa secara parsial terdapat pengaruh ROE terhadap zakat. Hal ini disebabkan jika ROE tinggi akan berdampak pada pendapatan laba yang meningkat sehingga kemampuan zakat akan bertambah. Sebaliknya jika ROE rendah akan berpengaruh terhadap kemampuan zakat yang semakin menurun.

\section{Uji Simultan (Uji F)}

Uji f pada dasarnya menunjukkan apakah semua variabel bebas yang dimaksudkan dalam model mempunyai pengaruh secara bersama-sama terhadap variabel terikat/dependen.

Tabel 10

Uji F

\begin{tabular}{|c|c|c|c|c|c|}
\hline Model & $\begin{array}{l}\text { Sum of } \\
\text { Squares }\end{array}$ & $\mathrm{df}$ & $\begin{array}{c}\text { Mean } \\
\text { Square }\end{array}$ & $\mathrm{F}$ & Sig. \\
\hline 1 Regression & 3,229 & 2 & 1,615 & 4,106 &, $026^{b}$ \\
\hline Residual & 12,978 & 33 & 393 & & \\
\hline Total & 16,208 & 35 & & & \\
\hline
\end{tabular}

a. Dependent Variable: ZAKAT

b. Predictors: (Constant), ROE, ROA

Berdasarkan Tabel 10 di atas dapat dilihat bahwa nilai $F_{\text {hitung }}$ sebesar 4,106 dan $F_{\text {tabel }}$ sebesar 3,28 sehingga $F_{\text {hitung }}$ lebih besar dari $F_{\text {tabel }}$ (4,106>3,28). Sehingga dapat diperoleh kesimpulan bahwa ROA dan ROE secara simultan berpengaruh terhadap zakat. Artinya perkembangan dari variabel zakat (Y) dapat dipengaruhi oleh kedua variabel bebas yaitu ROA (X1) dan ROE (X2).

\section{Pembahasan Hasil Penelitian}

\section{Pengaruh Return On Assets (ROA) terhadap Zakat pada PT. Bank Syariah Mandiri tahun 2008-2016}

Berdasarkan hasil penelitian yang dilakukan dengan menggunakan program SPSS versi 22, maka diperoleh hasil thitung variabel ROA sebesar -1,486 dengan nilai signifikan 0.147>0,05 maka $\mathrm{H}_{\mathrm{a}}$ ditolak. Berarti secara parsial tidak terdapat pengaruh signifikan ROA terhadap zakat. 
ROA tidak dapat digunakan untuk memprediksi zakat karena di uji secara parsial menunjukkan tidak ada pengaruh signifikan antara variabel X1 (ROA) terhadap variabel Y (zakat).

Hasil penelitian ini di dukung dengan penelitian terdahulu yang dilakukan Sri Zaitun. Dimana hasil penelitian Sri Zaitun menyatakan bahwa secara simultan faktor-faktor Return On Assets (ROA), Return On Equity (ROE), Loan Deposit Ratio (LDR), current rasio (CR), Debt to Assets Ration (DAR) dan Equty Multiflier (EM) berpengaruh secara statistik signifikan terhadap zakat, akan tetapi secara parsial hanya CR dan DAR saja yang berpengaruh secarah statistik signifikan terhadap zakat.

Berdasarkan hasil yang diperoleh peneliti terdahulu yaitu Sri Zaitun maka dapat dikatakan terdapat kesamaan hasil yang diperoleh dengan penelitian ini. Dimana variabel ROA (X1) secara parsial tidak memiliki pengaruh signifikan terhadap zakat.

\section{Pengaruh Return On Equity (ROE) terhadap Zakat pada PT. Bank Syariah Mandiri tahun 2008-2016}

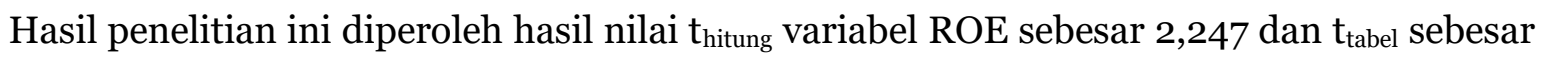
2,035 sehingga $t_{\text {hitung }}$ lebih besar dari $t_{\text {tabel }}$ (2,247>2,035), dengan nilai signifikan $0,031<0,05$ maka $\mathrm{H}_{\mathrm{o}}$ ditolak dan $\mathrm{H}_{\mathrm{a}}$ diterima. Sehingga dapat ditarik kesimpulan bahwa secara parsial terdapat pengaruh ROE terhadap zakat.

Hasil penelitian ini di dukung dengan penelitian terdahulu yang dilakukan Ichwan Sidik dan Reskino. Dimana mereka memperoleh hasil zakat memiliki pengaruh yang positif dan signifikan terhadap ROE..

Berdasarkan hasil yang diperoleh peneliti terdahulu yaitu Ichwan Sidik dan Reskino maka dapat dikatakan terdapat kesamaan hasil yang diperoleh dengan penelitian ini. Dimana variabel ROE (X2) secara parsial memiliki pengaruh signifikan terhadap zakat.

Pengaruh Return On Assets (ROA) dan Return On Equity (ROE) terhadap Zakat PT. Bank Syariah Mandiri Tahun 20o8-2016

Berdasarkan hasil penelitian yang dilakukan dengan menggunakan program SPSS versi 22, jika variabel independen di uji secara simultan terhadap variabel dependen maka diperoleh hasil nilai $F_{\text {hitung }}$ sebesar 4,106 dan $F_{\text {tabel }}$ sebesar 3,28 sehingga $F_{\text {hitung }}$ lebih besar dari $F_{\text {tabel }}$ $(4,106>3,28)$. Sehingga dapat diperoleh kesimpulan bahwa ROA dan ROE secara simultan berpengaruh terhadap zakat. Artinya perkembangan dari variabel zakat (Y) dapat dipengaruhi oleh kedua variabel bebas yaitu ROA (X1) dan ROE (X2).

Hasil penelitian ini didukung dengan penelitian terdahulu yang dilakukan Sri Zaitun, Ahmad Nurul Muammar, dan Khoirul Ikhwan . dimana Sri Zaitun memperoleh hasil variabel Return On Assets (ROA), Return On Equity (ROE), Loan Deposit Ratio (LDR), current rasio 
(CR), Debt to Assets Ration (DtAR) dan Equity Multiflier (EM) secara simultan berpengaruh secara statistik signifikan terhadap zakat. Ahmad Nurul Muammar memperoleh hasil rasio profitabilitas yang di ukur dengan ROA dan ROE secara bersama-sama (simultan) berpengaruh signifikan terhadap kemampuan zakat. Begitu pula hasil yang diperoleh Khoirul Ikhwan, hasil yang diperoleh menunjukkan bahwa variabel bebas (kinerja keuangan: profitabilitas, likuiditas, solvabilitas) secara bersamaan maupun sendiri mempunyai pengaruh yang kuat terhadap dana zakat. Variabel nilai kinerja keuangan mempunyai pengaruh yang dominan terhadap dana zakat. Ini sesuai dengan teori bahwa untuk pencapaian kinerja keuangan yang baik akan membuat kinerja zakat baik juga.

\section{KESIMPULAN}

Berdasarkan rumusan masalah yang telah dikemukakan maka dapat disimpulkan bahwa berdasarkan uji parsial (uji t) pada ROA dengan taraf nyata 5\% diperoleh nilai signifikan 0,147>0,05 maka Ha ditolak. Berarti secara parsial tidak terdapat pengaruh signifikan ROA terhadap zakat. Hal ini disebabkan ROA juga dipengaruhi total aset, sementara total aset pada BSM tidak selalu tetap. Sehingga total aset yang dimiliki mempunyai pengaruh yang besar dalam memoderasi pengaruh ROA terhadap zakat. Berdasarkan uji parsial (uji t) pada variabel ROE diperoleh nilai signifikan 0,031<0,05 maka Ho ditolak dan Ha diterima. Sehingga dapat ditarik kesimpulan bahwa secara parsial ROE berpengaruh signifikan terhadap zakat. Berdasarkan uji $\mathrm{F}$ dengan taraf nyata $5 \%$ maka diperoleh nilai $\mathrm{F}_{\text {hitung }}$ sebesar 4,106 dan $\mathrm{F}_{\text {tabel }}$ sebesar 3,28 sehingga $F_{\text {hitung }}$ lebih besar dari $F_{\text {tabel }}(4,106>3,28)$. Sehingga dapat diperoleh kesimpulan bahwa ROA dan ROE secara simultan berpengaruh terhadap zakat. Artinya perkembangan dari variabel zakat (Y) dapat dipengaruhi oleh kedua variabel bebas yaitu ROA (X1) dan ROE (X2). Berdasarkan hasil kesimpulan diatas penelitian dapat memberikan saran sebagai berikut bagi bank syariah yang sudah mampu (nisab) untuk menunaikan zakat dan perlu mempublikasikan laporan keuangan agar masyarakat mengetahui bahwa perbankan syariah sudah menunaikan zakat sesuai dengan prinsip syariah. Untuk meningkatkan pertumbuhan zakat maka dibutuhkan skala operasi yang cukup besar. Walaupun hanya berpengaruh sedikit kinerja keuangan mempunyai pengaruh terhadap zakat perusahaan, untuk mencapai angka pembayaran zakat yang tinggi maka terlebih dahulu meningkatkan kinerja keuangan secara menyeluruh. Bagi peneliti berikutnya diharapkanmenambah rasio keuangan lainnya sebagai variabel independen, karena sangat dimungkinkan rasio keuangan lain yang tidak dimasukkandalam penelitian ini berpengaruh terhadap kemampuan zakat. Kepada 
pembaca diharapkan setelah membaca skripsi ini dapat memberikan kritik dan saran demi kesempurnaan skripsi ini. Serta dapat menjadi rujukan dalam penelitian selanjutnya.

\section{DAFTAR PUSTAKA}

Andri Soemitra, Bank dan Lembaga Keuangan Syariah, Jakarta: Kencana, 2009.

Burhan Bungin, Metode Penelitian Kuantitatif: Komunikasi, Ekonomi, dan Kebijakan Publik Serta Ilmu Sosial Lainnya, Jakarta: Kencana Prenada Media Group, 2005.

Departemen Agama Republik Indonesia, Al Quran dan Terjemahannya, Jakarta: CV Darus Sunnah, 1998

Didin Hafidhuddin, Zakat Dan Perekonomian Modern, Jakarta: Gema Insani Press, 2002.

Duwi Priyatno, SPSS 2: Pemgolahan Data Terpraktis, Yogyakarta: CV. Andi Offset, 2014.

Dwi Suwiknyo, Analisis Laporan Keuangan Perbankan Syariah, Yogyakarta: Pustaka Pelajar, 2010.

Hery Sutanto dan Kherul Umam, Manajemen Pemasaran Bank Syariah, Bandung: Pustaka Setia, 2013

Ismail, Perbankan Syariah, Jakarta: Kencana, 2011.

Iwan Triyuwono, Perspektif, Metodologi, Dan Teori: Akuntansi Syariah, Jakarta: Rajawali Pers, 2009.

Jonathan Sarwono, Rumus-rumus dalam SPSS 22 untuk Riset Skripsi, Yogyakarta: Andi, 2005. dan Tutty Martadiredja, Riset Bisnis Untuk Pengambilan Keputusan, Yogyakarta: Andi Offset, 2008.

Jumingan, Analisis Laporan Keuangan, Jakarta: PT. Bumi Aksara, 2011.

Kasmir, Analisis Laporan Keuangan, Jakarta: Rajawali Pers, 2012. , Manajemen Perbankan, Jakarta: Rajawali Pers, 2014.

Khaerul Umam, Manajemen Perbankan Syariah, Bandung: Pustaka Setia, 2013.

Morrisan, Metode Penelitian Survei, Jakarta: Kencana , 2012.

Muhammad Firdaus, Ekonometrika Suatu Pendekatan Aplikatif, Jakarta: Bumi Aksara, 2011.

Muhammad, Pengantar Akuntansi Syariah, Jakarta: Salemba Empat, 2002.

JISFIM: Journal of Islamic Social Finance Management, Volume 1, No 2 Tahun 2020 http://jurnal.iain-padangsidimpuan.ac.id/index.php/JISFIM 
, Bank Syariah Problen dan Prospek Perkembangan di Indonesia, Yogyakarta: Graha Ilmu, 2005.

, Metodologi Penelitian Ekonomi Islam: Pendekatan Kuantitatif, Jakarta: PT. Rajawali Press, 2008.

Murti Sumami \& Salamah Wahyuni, Metodologo Penelitian Bisnis, Yogyakarta: CV. Andi Offset, 2006.

Nachrowi Djalal, Ekonometrika Untuk Analisis Ekonomi dan Keuangan, Jakarta: Lembaga Penerbit Fakultas Ekonomi Universitas Indonesia, 2006.

Rizal Yaya, dkk, Akuntansi Perbankan Syariah Teori dan Praktik Kontemporer, Jakarta: Salemba Empat, 2014.

Slamet Haryono, Analisis Laporan Keuangan Perbankan Syariah cet. 1, Indramayu: Pustaka Sayid Sabiq, 2009.

Sri Nurhayati, Akuntansi Syariah Di Indonesia, Jakarta: Salemba Empat, 2014.

Sugiyono, Metode Penelitian Bisnis, Bandung: Alfabeta, 2005.

Suharsimi Arikunto, Prosedur Penelitian Suatu Pendekatan Praktik, Jakarta: PT Rineka Cipta, 2006.

Suliyanto, Analisis Data dalam Aplikasi Pemasaran, Bogor: Ghalia Indonesia, 2005

Triton Prawira Budi, SPSS 13,o Terapan, Yogyakarta: CV. Andi, 2006.

Umrotul Khasanah, Manajemen Zakat Modern Instrumen Pemberdayaan Ekonomi Umat, Malang: UIN-Maliki Press, 2010.

Veithzal Rivai dan Andria Permata Veithzal, Islamic Financial Management, Jakarta: PT. Raja Grafindo Persada, 2008.

dan Arviyan Arifin, Islamic Banking, Jakarta: PT. Bumi Aksara, 2010.

JISFIM: Journal of Islamic Social Finance Management, Volume 1, No 2 Tahun 2020 http://jurnal.iain-padangsidimpuan.ac.id/index.php/JISFIM 